\title{
Impact of teacher education abroad in international co-authorship: a study of Federal University of São Carlos's scientifics production indexed in the Web of Science
}

\author{
Impacto da formação docente no exterior na \\ coautoria internacional: estudo da produção \\ científica da Universidade Federal de São \\ Carlos indexada na Web of Science
}

\author{
José Eduardo dos REIS 1 (iD) 0000-0002-6568-9158 \\ Denilson de Oliveira SARVO 1 (D) 0000-0002-4374-6430 \\ Leandro Innocentini Lopes de FARIA² (i) 0000-0002-8369-1315 \\ Roniberto Morato do AMARAL 2 (i) 0000-0002-9816-231X
}

\begin{abstract}
Metric studies on internationalization, especially indicators of co-authorship, present challenges regarding the collection, representativeness, and reliability of the data measuring the impacts of international mobility. Aiming to contribute to the understanding of scientific collaboration initiatives, the present research's objective was to investigate the relationship between outside teacher education, represented by the completion of a doctoral degree and post-doctoral internship, and international collaboration, identified by the international co-authorships in institutional scientific output. The research method was the exploratory case study, and the case unit was the Federal University of São Carlos. The Lattes Platform and the Web of Science were used as sources of information, and the sample analyzed comprised 12,787 scientific articles and 1,915 Lattes resumés. It was found that 1,850 teachers have doctoral or post-doctoral education (96.6\%) and, of these, 632 graduated abroad (33.1\%). Regarding the scientific output, 3,487 of the 12,787 articles were published in international co-authorship (27.3\%). From the scientific output in international co-authorship, indicators on the groups of teachers with and without education abroad were analyzed. Among the indicators developed, 8.43 articles per teacher were identified for the group with education abroad, while in the group without education abroad, 4.26 articles were identified per teacher. The results demonstrate a positive relationship between doctoral or post-doctoral education abroad with international co-authorships, contributing to institutional internationalization.
\end{abstract}

Keywords: Analysis of scientific output. Bibliometry. Internationalization. Postgraduate studies. Scientific collaboration.

\footnotetext{
1 Universidade Federal de São Carlos, Centro de Educação e Ciências Humanas, Programa de Pós-Graduação em Ciência, Tecnologia e Sociedade. Rod. Washington Luis, km 235, 13565-905, São Carlos, SP, Brasil. Correspondência para/Correspondence to: J.E. REIS. E-mail: <reis.unicep@gmail.com>.

2 Universidade Federal de São Carlos, Centro de Educação e Ciências Humanas, Departamento de Ciência da Informação. São Carlos, SP, Brasil. Received on September 2, 2020, final version resubmitted on August 2, 2021, and approved on October 25, 2021.
}

Como citar este artigo/How to cite this article

Reis, J. E. et al. Impact of teacher education abroad in international co-authorship: a study of Federal University of São Carlos's scientifics production indexed in the Web of Science. Transinformação, v. 33, e200061, 2021. https://doi.org/10.1590/2318-0889202133e200061 


\section{Resumo}

Os estudos métricos sobre a internacionalização, em especial os indicadores de coautoria, apresentam desafios quanto à coleta, representatividade e confiabilidade de dados voltados à mensuração dos impactos da mobilidade internacional. Visando contribuir para a compreensão das iniciativas de colaboração científica, o objetivo da pesquisa foi investigar as relações entre a formação docente no exterior, representada pela realização de curso de doutorado e estágio de pós-doutorado, e a colaboração internacional, identificada pelas coautorias internacionais presentes na produção científica institucional. O método de pesquisa foi o estudo de caso exploratório, e a unidade-caso, a Universidade Federal de São Carlos. A Plataforma Lattes e a Web of Science foram utilizadas como fontes de informação, e a amostra analisada compreendeu 12.787 artigos científicos e 1.915 Currículos Lattes. Verificou-se que 1.850 docentes possuem formação de doutorado ou pós-doutorado (96,6\%) e, destes, 632 se formaram no exterior (33,1\%). Com relação a produção científica, dos 12.787 artigos, 3.487 foram publicados em coautoria internacional (27,3\%). A partir da produção científica em coautoria internacional foram analisados indicadores sobre os grupos de docentes, com e sem formação no exterior. Entre os indicadores elaborados, foi identificado um número de 8,43 artigos por docente, para o grupo com formação no exterior, enquanto no grupo sem formação no exterior foi apresentado um nUFSmero de 4,26 artigos por docente. Os resultados obtidos demonstram que há uma relação positiva entre a formação docente de doutorado ou pós-doutorado no exterior com as coautorias internacionais, contribuindo para a internacionalização institucional.

Palavras-chave: Análise da produção científica. Bibliometria. Internacionalização. Pós-graduação. Colaboração científica.

\section{Introduction}

Social studies of science begin with the observation of scientists' behaviors, the constitution of scientific communities, and science's interaction with society. There is a growing tendency of international communication in the scientific field involving multiple institutions in various countries. The concept of scientific communication refers to the production, consumption, and transference of information in the scientific field. Caribé (2015) relates it with the popularization, diffusion, and dissemination of science. With the rise of information technologies, scientific communication became more complex and dynamic, promoting the collaboration between national and international researchers.

Gibbons et al. (1994) pointed to the changes from a disciplinary lab-based researcher-oriented science housed in universities and large institutions, to a multidisciplinary and network-supported form of science oriented to solving society's problems and facing its challenges. These characteristics are present in contemporary science, resulting in a new form of scientific knowledge production, based on scientific collaboration, that reforms institutions, disciplines, practices, and politics (Gibbons et al., 1994). In the same sense, Bonaccorsi and Vargas (2010) identified growing dynamics of knowledge production related to the proliferation of new scientific subareas. These dynamics are making it easier to overcome national and international problems of communication among researchers who speak different languages and consequently, allowing more interaction between various knowledge areas. These interactions are crucial in knowledge-sharing processes, boosting human creativity and new ideas (Cugmas et al., 2020).

The definitions of collaborative scientific work include two elements: working together for a common goal and sharing knowledge (Cugmas et al., 2020). For instance, such work includes moments of collaboration between two scientists, sharing data, intellectual, economic, or physic resources like materials, equipment, and/or ideas in a project that results in research experiments and analyses (or not) published as articles (Bordons; Gómez, 2000). Imperative in many areas, scientific collaboration improves researchers' access and integration of knowledge, skills, materials, and other resources needed to deal with scientific problems. It currently constitutes a work strategy adopted to enable, potentialize, or make research easier, especially empiric or experimental research (Zhang et al., 2018).

Scientific collaboration can take many forms, such as sharing equipment, infrastructure, and knowledge, and it does not always happen formally, making it harder to monitor. Among the forms of scientific collaboration, we 
highlight co-authorship, a relation between authors through joint publications. Despite its limitations, Solla Price and other pioneers of metric studies consider the multi-author publication the basic unit of scientific collaboration (Katz; Martin, 1997). Cugmas et al. (2020) point to co-authorship as one of the most formal expressions of scientific collaboration, inciting studies on individual and organizational relations of scientific collaboration.

Recognizing that co-authorship is representative of collaboration includes considering its various levels in individuals, research groups, departments, institutions, areas, and nations. According to Katz and Martin (1997), international collaboration is collaboration "among nations" and publications in those circumstances may take many forms. An institution's international collaboration is represented by the number of publications in which at least one author of this institution and one author from an institution of another country figure together.

Academic interaction and international scientific collaboration became essential for the solution of complex problems (Yao et al., 2020) in the context of globalization. In terms of public policy, since 2017, the Coordenação de Aperfeiçoamento de Pessoal de Nível Superior (Capes, Coordination for Higher Education Staff Development) funds the Programa Institucional de Internacionalização (Capes-PrInt, Institutional Program of Internationalization) to propel engagement in international scientific spaces and to integrate Capes's projects of internationalization (Coordenação de Aperfeiçoamento de Pessoal de Nível Superior, 2020). Internationalization may be understood as (1) a broad opening of national institutions to social and external relations; (2) a way to increase or generate specific educational, scientific, and technological competencies (Lombas, 2013); (3) a possibility of increasing the conditions of an international collaborative environment in universities (Prolo et al., 2019); and (4) and a means through which the mobility of students, professors, and researchers is increased (Granja, 2018). Among practices of internationalization, international mobility occurs when researchers move from one place to another, seeking to obtain the desired knowledge with in-person scientific collaboration (Aman, 2020).

Among the recent research on the internationalization of Brazilian science, the following works stand out: (1) Ramos's (2018) analysis of Brazil's approaches to adapting the education of Ph.D. holders to the mobilization, collaboration, and internationalization of higher education and research from the 1990s onwards; (2) Using data from the Scimago Journal \& Country Rank, Madeira and Marenco (2016) mapped the routes and dynamics of international mobility, pointing to challenges for internationalization listed in the Plano Nacional de Pós-Graduação (National Graduate Plan); (3) Prolo et al. (2019) claimed that the policy Ciência sem Fronteiras (CsF, Science Without Borders) potentialized Brazilian universities' exposure to the international environment, contributing to international academic partnerships and networks and influencing the model of internationalization of higher education proposed by the Brazilian government. According to the authors, CsF led a broader and more organic process of institutionalization of Brazilian universities and amplified their ability to develop international environments of research. (4) Granja (2018) also assessed the CsF and concluded that its short-term results for the Universidade Estadual de Campinas (State University of Campinas) were timid due to the program's high costs. Despite positive institutional effects in under graduation courses and in the university's internationalization, they were modest, limited, and accompanied by a series of administrative problems. (5) Finally, Lombas (2013) demonstrated that greater exposition to the international environment, which comprises a full Ph.D. and a post-doctoral internship abroad, favor the diversification of initiatives for increasing relations with foreign institutions.

According to Grácio et al. (2018), international partnerships strongly contribute to the increase of universities' scientific production and may be quantified by bibliometric studies. Among the elements indicators may measure, the level and impact of internationalization may be calculated by the article citations and co-authorship relations. Bonaccorsi and Thoma (2007) affirm that indexes are being created to analyze researchers' performance considering the production of patents and scientific production. Among these indicators, forms of monitoring internationalization activities are relevant for institutional evaluations in the international rankings of universities, strategic graduation planning, and public policies for the internationalization of Brazilian science. 
With the dissemination of databases, bibliometric indicators became more utilized and recommended as sources of scientific and technological information. Making bibliographic information available potentialized online scientific communication, maximizing the automatic production of scientific indicators (Glänzel; Moed, 2002). Although databases have largely been made available, challenges for metric studies remain, especially those pertaining to data collection. Grácio et al. (2018) point to the lack of representativeness and trustworthiness of the samples obtained, the lack of normalization for author and affiliation-related information, and language barriers. The Leiden Manifesto points to inadequate analyzes of indicators as prejudicious to science (Hicks et al., 2015).

To map and understand internationalization, several metric studies were based on documents available on databases like the Web of Science (WoS) and Scopus (Dias et al., 2019). While those are structured sources of information, the lack of standardization by authority controls conferred to authors and institutions, which ensure the complete recovery of a specific institution's production, among other factors, poses challenges for metric studies.

Like other bibliographic databases, the WoS has been looking to improve the standardization of authority in publications for institutions and authors. A list was introduced many years ago with institutions' preferential names and their main variations. Preferential names are available in bibliographic records in the field "Organization - Enhanced". Though new variations are common, the list is updated frequently - the very institutions require it sometimes - and preferential names allow an efficient indexation of publications to institutions. As for authors, two problems are common in indexing publications: either the publication cannot be connected to an author because of variations in author name spelling, or publications whose authors have the same name may be connected to the wrong author. These problems have been addressed with the introduction of persistent author identifiers - first with ResearcherID, exclusively for WoS, and then with the Open Researcher and Contributor Identifier (ORCID), supported by a consortium of institutions (Craft, 2020). However, not all authors have ORCID numbers and not every journal allows introducing them in authorship. The current authority control in WoS allows connecting publications to institutions with a good precision level but doing so to the author remains challenging.

The Lattes Platform (LP) is a database of academic resumés that records scientific production. Initially developed for the evaluation and progression of the teaching career and for managing the research financed by the Conselho Nacional de Desenvolvimento Científico e Tecnológico (CNPq, National Council for Scientific and Technological Development), it contains a range of information on researchers, including their institutional affiliation, finished and ongoing projects, stages of formation, and scientific production. The LP is a valid source of information for metric studies used by the government, financing agencies, research groups, among others (Conselho Nacional de Desenvolvimento Científico e Tecnológico, 2020). Thus, several metric studies have used data from the LP. For instance, Dias et al. (2019) studied the networks of scientific collaboration between Brazilian researchers using the Lattes resumés; Damaceno et al. (2019) performed a quantitative analysis mapping academic genealogies; Lança et al. (2018) investigated the interdisciplinary relations in Information Science graduation courses. A positive point of the LP is IDLattes, a 16-digit code employed by CNPq to identify each Lattes resumé (Mena-Chalco et al., 2012), which allows the effective connection of publications to each of their authors. Despite their contribution to metric studies, the LP presents challenges related to the lack of information on institutional affiliation, for two reasons: (1) it does not include foreign authors' resumés; (2) the LP's metadata does not include the foreign authors and coauthors' institutional affiliation.

One cannot download bibliographic records of publications from the LP like in bibliographic databases like WoS. The resumés with the publications' bibliographic data may be recovered manually in each resumé, in XML format, or using an extraction tool CNPq offers to partner institutions. Solutions developed by the research groups automatize the joint collection of resumés with a web interface to consult the LP or with the extraction tool, and promote the treatment of data, making lists of bibliographic records, doubled publications, disambiguation of authorship, counting publications, and making graphic indicators and networks. Some of these tools are ScriptLattes, SyncLattes, and Somos, and all use IDLattes to recover resumés (Matias, 2015). 
According to Bassoli (2017), WoS and LP's indexed publications are highly intersecting. In the case of Universidade Federal de São Carlos (UFSCar, Federal University of São Carlos), 9,295 (66.3\%) of the 14,013 articles of the university indexed in WoS are also in their authors' resumés in LP. Inversely, 9,295 (33.7\%) of the 27,561 articles from UFSCar indexed in the LP are also indexed in WoS. According to Bassoli (2017, p. 59, our translation)3," "[...] both datasets are samples of UFSCar's universe of publications since none of them covers the total publications of any institution".

Neither the WoS nor the LP is sufficient in isolation to study the relation between teachers' education abroad and international scientific collaboration in a given university. The LP presents data on a researcher's education, when, on which institution and country its stages took place. It allows the analysis of the stages of education abroad (if any) for a given group of researchers - such as the teachers in a university. Regarding analyzes of international scientific collaboration, the LP should contain records on the authors' institutional affiliation in internship levels and on participation in research groups. It still has limitations in that sense, as the data on scientific publications in the resumés do not include information regarding the co-authors' institutional affiliations and most international partners do not have a resumé in the LP.

The WoS contains information on each author's national institutional affiliation. As this database allows searching publications per institution, one may identify the international collaboration for a publication (or lack thereof). However, the WoS does not provide information on the authors' education, making it impossible to attribute publications to authors with or without education abroad. Associating the publications with and without institutional collaboration found in the WoS with the researchers with and without a stage of formation abroad identified by the LP cannot be done directly, as the WoS and LP use different and unrelated indicators of authorship.

Therefore, the bibliographic records of the same publication contain different information in each of the bases. Identifying the publication in both the WOS and LP may be done by comparing common data among the bibliographic records, using persistent indicators of publication, Digital Object Identifier System, International Standard Serial Number (ISSN), among others. Records could be enriched with information from both bases, broadening the metric analyses.

Seeking to contribute to the understanding of initiatives of scientific collaboration with metric studies, our goal in this study was to examine the relations between international education (Ph.D. or post-doctorate abroad) and the effects in international co-authorship in the scientific production of UFSCar indexed in the WoS and recorded in the LP. The study applied a new procedure for enriching WoS's bibliographic data with IDLattes.

\section{Methodological Procedures}

The research is an exploratory applied case study with a quantitative approach. The case unit was UFSCar, a public university in the state of São Paulo selected for being a renowned higher education institution recognized for its excellent research in Brazil and Latin America, according to The Times Higher Education Ranking (2021), where it occupies $12^{\text {th }}$ place in teaching and $9^{\text {th }}$ in research among 52 Brazilian universities. Federal University of São Carlos offers 65 under graduation courses and 91 graduate courses in 54 graduate programs from various knowledge areas in four campi - São Carlos, Araras, Sorocaba, and Lagoa do Sino, in the city of Buri.

Metric studies about UFSCar's scientific production using the LP as a data source are found in: Matias (2015), who used it for the automated settlement of institutional repositories; Bassioli (2017), who evaluated the LP as a source of data for elaborating institutional indicators in comparison with WoS; Franco and Faria (2019), who mapped

\footnotetext{
3 In original: "[...] ambos os conjuntos de dados são amostras do universo de publicações da UFSCar, uma vez que nenhuma das duas bases de dados cobre a totalidade das publicações de qualquer instituição" (Bassoli, 2017, p. 59).
} 
intra-organizational scientific collaboration; and in Lança et al. (2018), who identified the multi and interdisciplinary relations in graduate levels.

The present research's bibliometric study used the LP and WOS as sources of information and data enrichment. It sought to minimize the limitations in identifying institutional affiliations and forming researchers. The research counted on a fusion of data from WoS and LP to investigate the relationship between international teacher education (Ph.D. or post-doctorate levels) and international scientific collaboration through the analysis of co-authorship in scientific production. Figure 1 illustrates the stages of the experimental procedure.

\section{Stage 1 - Recovering registers in the Lattes Platform with SyncLattes}

We recovered the metadata on UFSCar's institutional scientific production from the LP, identifying the institutional affiliation and formation (Ph.D. or post-doctorate) of 1,915 active teachers. Comprising 35,365 bibliographic records of articles, UFSCar's scientific production indexed in the LP was obtained in February 2020 with the SyncLattes tool (Matias, 2015; Lança et al., 2018; Franco; Faria, 2019). The metadata obtained in the LP is not sufficient for producing internationalization and co-authorship indicators based on co-authors' institutional affiliations.

\section{Stage 2 - Recover the institutional scientific production in the WoS}

The WoS was used as a source of information for data enrichment, seeking to identify the institutions to which the co-authors of UFSCar teachers' production were affiliated. The research in February 2020 selected the

STAGE 1 - Lattes Recovery: SyncLattes

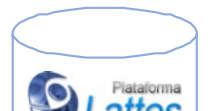

35,365 records

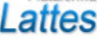

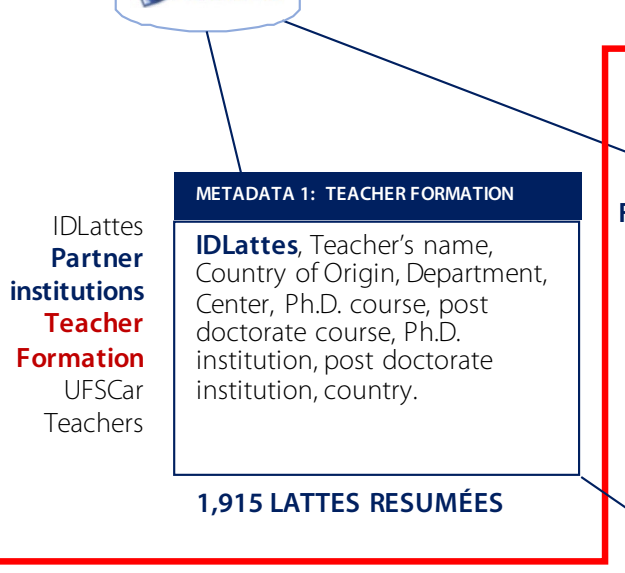

STAGE 3 - Treatment of the recovered data Authority control: institutions, countries, authors, areas, departments, centers...
STAGE 2 - WoS Recovery: Organization-Enhanced

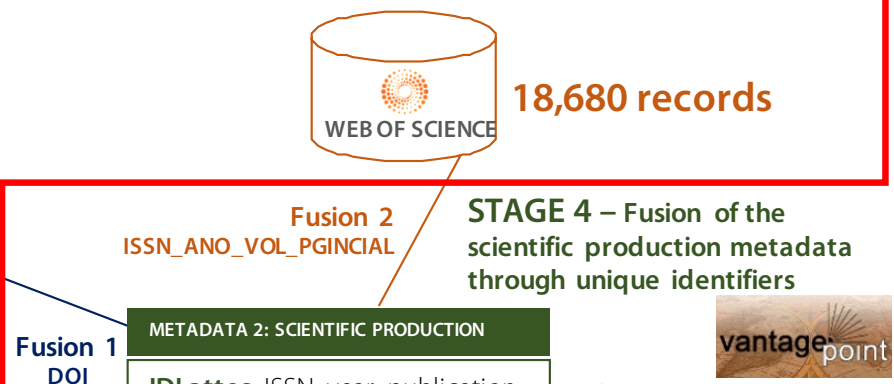

STAGE 5 - Indicators of the impact of teacher formation in collaboration and scientific formation

IDLattes, ISSN, year, publication - IDLattes volume, initial page of publication, title, name(s) of author(s), country of authors, number of citations.
- Partner institutions (intellectual production)

- Teachers in UFSCar - DOI - ISSN_ANO_VOL_PGINCIAL

Figure 1 - Stages of the experimental procedure.

Source: Elaborated by the authors (2020). 
field "Organization - Enhanced" and the search expression "Universidade Federal de São Carlos". It recovered 18,680 articles related to institutional scientific production indexed in the main data collection of the WoS.

\section{Stage 3 - Treatment of the recovered data}

Sought to apply authority control and standardize information involving the naming of countries, institutions, organizational units (departments, centers, etc.), and knowledge areas. The metadata from the LP and the WoS were imported to the software VantagePoint and treated with controlled filters and vocabularies previously developed by the Núcleo de Informação Tecnológica em Materiais (Materiais, Nucleus of Technological Information on Material) of UFSCar. The purpose of making controlled vocabularies, named by Vantage Point as Thesaurus, was to select preferred terms, as the same term allows various readings. This selection is relevant for recovering information (Fujita; Tolaire, 2019).

\section{Stage 4 - Fusions through unique identifiers}

Merging the LP and WoS registers relied on two key fields for the database's metadata: (1) DOI, used for characterizing and recovering scientific production; (2) ISSN_ANO_VOL_PGINICIAL, created with the union of the fields ISSN, YEAR, VOLUME, and INITIAL PAGE OF PUBLICATION. The results of the fusion enabled identifying a sample of 12,787 bibliographic registers present in both bases, represented in the field "Metadata 2 - Scientific Production" of Figure 1.

The group of 12,787 articles has the authorship of 1,176 UFSCar teachers. The reduction from 1,915 teachers in the initial sample to 1,176 is because not all teachers had their production indexed in WoS.

The data enrichment with the fusion of registers allowed identifying co-authors' institutional affiliations. It required metadata from the WoS, as the LP does not present data on co-authors' institutional connections and countries.

\section{Stage 5 - Indicators on the impact of teacher formation in UFSCar's international co-authorship}

Seeking to produce indicators related to teacher formation (Ph.D. and/or post-doctorate) and institutional scientific production, we recovered data on the formation of 1,915 UFSCar teachers registered in the Lattes Platform. After the recovery, the data were included as attributes in "Metadata 2 - Scientific Production" (Figure 1) with the help of their IDLattes.

With the sampling of scientific production bibliographic records enriched with the fusion of the WoS and LP metadata and the inclusion of the "teaching formation" attribute, we elaborated a group of indicators on UFSCar's scientific production. We considered the authorship of researchers from foreign institutions and the influence of teachers' education abroad (Stage 5 in Figure 1).

\section{Results and Discussion}

Indicators on the teachers, their education abroad or lack thereof, the number of international publications, citations, and co-authorships were elaborated from the data on their scientific production with international collaboration. Our sample comprised 1,915 Lattes resumés (initial sample of teachers) and 12,787 bibliographic records gathered from both the LP and WoS, which corresponded to UFSCar teachers' scientific production.

Of the initial sample of 1,915 teachers, 632 (33.1\%) teachers had done their Ph.D. or post-doctorate degree abroad and 1,283 (66.9\%) had not. The indicator in Table 1 shows the distribution of Ph.D. and post-doctorates done 
in Brazil and abroad for the 1,915 teachers. According to the data, most teachers were educated in Brazil, with 2,347 teachers formed in national institutions (74.8\%) versus 789 (25.2\%) in educated 33 foreign countries. This difference aside, the number of post-doctors who graduated in Brazil and abroad is balanced, with an excess of only 25 formations in Brazil. No similar balance is found for the Ph.D., with 1,533 more people having had their formation in Brazil than in foreign institutions.

Considering the teachers educated in Brazil, $72.6 \%$ have a Ph.D. and 27.6\% have a post-doctorate degree. Among those with foreign formation, the numbers are inverse: $21.7 \%$ of them earned their Ph.D. abroad, against

Table 1 - Comparison between Ph.D. and post-doctorate formation abroad and the number of teachers.

\begin{tabular}{|c|c|c|c|c|}
\hline \multirow{2}{*}{ Formation } & Ph.D & Post-doctorate & \multirow{2}{*}{ Total Formation [Ph.D] + [Post-doctorate] } & \multirow{2}{*}{ Number of teachers } \\
\hline & n (\%) & n (\%) & & \\
\hline United States & $46(17.9)$ & $211(82.1)$ & 257 & 241 \\
\hline United Kingdom & $37(32.2)$ & $78(67.8)$ & 115 & 108 \\
\hline France & $36(32.4)$ & $75(67.6)$ & 111 & 98 \\
\hline Canada & $6(10.7)$ & $50(89.3)$ & 56 & 54 \\
\hline Spain & $6(10.9)$ & $49(89.1)$ & 55 & 55 \\
\hline Germany & $13(29.5)$ & $31(70.5)$ & 44 & 42 \\
\hline Portugal & $3(8.3)$ & $33(91.7)$ & 36 & 36 \\
\hline Italy & $4(18.2)$ & $18(81.8)$ & 22 & 22 \\
\hline Bélgium & $3(18.8)$ & $13(81.3)$ & 16 & 14 \\
\hline Japan & $5(38.5)$ & $8(61.5)$ & 13 & 11 \\
\hline Denmark & $3(33.3)$ & $6(66.7)$ & 9 & 9 \\
\hline Australia & $0(0.0)$ & $8(100.0)$ & 8 & 8 \\
\hline Argentina & $2(28.6)$ & $5(71.4)$ & 7 & 6 \\
\hline Sweden & $0(0.0)$ & $4(100.0)$ & 4 & 4 \\
\hline Norway & $0(0.0)$ & $2(100.0)$ & 2 & 2 \\
\hline Austria & $0(0.0)$ & $2(100.0)$ & 2 & 2 \\
\hline Finland & $0(0.0)$ & $2(100.0)$ & 2 & 2 \\
\hline Czech Republic & $1(50.0)$ & $1(50.0)$ & 2 & 2 \\
\hline Israel & $0(0.0)$ & $2(100.0)$ & 2 & 2 \\
\hline Uruguay & $1(50.0)$ & $1(50.0)$ & 2 & 2 \\
\hline Ireland & $0(0.0)$ & $2(100.0)$ & 2 & 2 \\
\hline Russia & $1(100.0)$ & $0(0.0)$ & 1 & 1 \\
\hline South Africa & $0(0.0)$ & $1(100.0)$ & 1 & 1 \\
\hline Switzerland & $0(0.0)$ & $1(100.0)$ & 1 & 1 \\
\hline New Zealand & $0(0.0)$ & $1(100.0)$ & 1 & 1 \\
\hline China & $0(0.0)$ & $1(100.0)$ & 1 & 1 \\
\hline Paraguay & $1(100.0)$ & $0(0.0)$ & 1 & 1 \\
\hline Slovenia & $0(0.0)$ & $1(100.0)$ & 1 & 1 \\
\hline Polland & $0(0.0)$ & $1(100.0)$ & 1 & 1 \\
\hline Colombia & $0(0.0)$ & $1(100.0)$ & 1 & 1 \\
\hline Chile & $0(0.0)$ & $1(100.0)$ & 1 & 1 \\
\hline Total abroad formation & $171(21.7)$ & $618(78.3)$ & 789 & 632 \\
\hline Total national formation & $1,704(72.6)$ & $643(27.4)$ & 2,347 & 1,748 \\
\hline Total general formation & $1,875(59.8)$ & $1,261(40.2)$ & 3,136 & $1,850^{*}$ \\
\hline
\end{tabular}

Note: ${ }^{*}$ There is a difference of 65 teachers from the initial sample, with 1,915 teachers left. The ones excluded did not have complete Ph.D. or post-doctorate levels. Source: Elaborated by the authors (2020). 
78.3\% for the post-doctorate. The results certify those of Radael et al. (2019), who posit that this typology of foreign formation is more significant and may be related to the graduate programs'search for a better evaluation in Capes's system.

The data presented in Table 1, with 65 teachers excluded from the initial sample is justified by levels of education before the Ph.D. (54 of them held a master's degree; 7, a specialization degree; 3, undergraduate degrees; and 1 whose Lattes profile was not complete). Among the teachers, 962 did not have a post-doctorate. The quantitative analysis comparing those with a Ph.D. and a post-doctorate versus the total number of teachers shows that there were teachers with more than one formation. For instance, while there were 1,850 Ph.D. holders, 1,875 Ph.D. formations had been computed.

Among the countries of formation for Ph.D. and post-doctorate levels, institutions in the United States, United Kingdom, France, Canada, and Spain prevail. These are among the most important countries to collaborate in Brazilian scientific production (Thiengo et al., 2018).

The intensity of the scientific collaboration between UFSCar's teachers and researchers affiliated to foreign institutions is noticed in Table 2. Among the group of teachers with foreign education, international co-authorships include authors from 97 countries. The 33 countries in Table 2 coincide with those international co-authorships related to UFSCar teachers' Ph.D. or post-doctorate education abroad. The table also shows the intensity of collaboration in international co-authorship for the teachers with and without foreign formation, allowing a vision of the volume of published articles and their countries of origin.

The sample of 12,787 articles corresponds to the scientific production indexed in WoS. Among these, 3,487 (27.3\%) were produced with international co-authorship and 9,300 (72.7\%) did not present international co-authorship.

To assess the relation between teachers' foreign formation and international co-authorship, we examined the universe of UFSCar's articles produced in international co-authorship, a total of 3,487 articles, as well as the co-authorship of 1,176 teachers in UFSCar with and without foreign education (an average of 10.8 articles per teacher).

Analyzing the production of the two groups, 328 teachers with foreign education had 1,766 articles (8.43 articles per teacher) published with international co-authorship. Among the 301 teachers in UFSCar without foreign education, we found 1,284 articles published in international co-authorship, an average of 4.26 articles per teacher. Thus, the group with international education has a higher article-per-teacher ratio (8.43) compared to the group without foreign formation (4.26). This indicator shows the influence of foreign formation in the establishment of international scientific collaboration through co-authorship. In this sense, it corroborates the study of Grácio et al. (2018) affirming that international partnerships contribute to increasing scientific productivity in universities, as well as that of Ramos (2018), that highlights international mobility and collaboration as factors that impact research, increase researchers' productivity and students' international engagement.

The relations between the teachers, the number of articles, and the countries in collaboration were considered in the co-authorship numbers. Thus, each co-authorship relationship was counted independently when it occurred more than once in the same publication; when an article was written by more than one teacher from UFSCar, they were counted individually. For instance, 173 teachers published 683 articles in the United States with researchers identified by the WoS as affiliated with American institutions, as described in Stage 4 of Methods. In the same line of the table, the number 138 refers to the total number of teachers without any formation abroad, who published 305 articles in co-authorship with American-based researchers.

As the data in Table 2 shows, no direct relation was found between increased international co-authorships and teachers' formation abroad. The overall average of the sample is 2.1 international co-authorship articles per teacher among those with foreign formation and 1.7 articles for teachers without foreign formation. For example, Spain presents 2.9 articles per teacher with foreign formation periods and 3.2 articles for each teacher without foreign education. Regarding the three countries with the largest co-authorship numbers with UFSCar researchers, the United States, the United Kingdom, and France (1,256 articles), the ratio is 3.1 articles per teacher with international formation and 2.0 articles per teacher without international formation. 
According to data provided by the Organization for Economic Co-operation and Development in 2014, 52\% of all global international student mobility is concentrated in six countries: the United States, the United Kingdom, Germany, France, Australia, and Canada. Moreover, 30\% of students searching for higher education abroad choose American or British universities. These countries house many internationally high-ranked educational institutions (Thiengo et al., 2018). The numbers presented in Table 2 agree with this perspective, identifying the intensification of mobility in UFSCar as similar to that of those countries.

In Latin American countries, the number of articles per teacher does not vary significantly according to foreign formation (1.9 for those who studied abroad and 1.2 for those formed in national institutions). However,

Table 2 - Scientific production in co-authorship with the identified countries of teacher formation.

\begin{tabular}{|c|c|c|c|c|c|c|c|}
\hline \multirow[b]{2}{*}{ Country } & \multirow[b]{2}{*}{$\begin{array}{c}\text { Teachers who } \\
\text { graduated in } \\
\text { Brazil }\end{array}$} & \multicolumn{3}{|c|}{ With foreign formation } & \multicolumn{3}{|c|}{ Without foreign formation } \\
\hline & & $\begin{array}{l}\text { Teachers who } \\
\text { published } \\
\text { articles with } \\
\text { national authors }\end{array}$ & $\begin{array}{c}\text { Articles in } \\
\text { co-authorship } \\
\text { with national } \\
\text { authors }\end{array}$ & $\begin{array}{c}\text { Articles } \\
\text { per } \\
\text { teacher }\end{array}$ & $\begin{array}{c}\text { Teachers who } \\
\text { published } \\
\text { articles with } \\
\text { national } \\
\text { authors }\end{array}$ & $\begin{array}{c}\text { Articles in } \\
\text { co-authorship } \\
\text { with national } \\
\text { authors }\end{array}$ & $\begin{array}{c}\text { Articles per } \\
\text { teacher }\end{array}$ \\
\hline United states & 241 & 173 & 683 & 3.9 & 138 & 305 & 2.2 \\
\hline United Kingdom & 108 & 132 & 295 & 2.2 & 73 & 157 & 2.1 \\
\hline France & 98 & 92 & 287 & 3.1 & 55 & 96 & 1.7 \\
\hline Spain & 55 & 107 & 314 & 2.9 & 66 & 210 & 3.2 \\
\hline Canada & 54 & 96 & 202 & 2.1 & 43 & 80 & 1.9 \\
\hline Germany & 42 & 106 & 303 & 2.9 & 54 & 123 & 2.3 \\
\hline Portugal & 36 & 72 & 131 & 1.8 & 43 & 67 & 1.6 \\
\hline Italy & 22 & 57 & 139 & 2.4 & 27 & 62 & 2.3 \\
\hline Belgium & 14 & 31 & 50 & 1.6 & 22 & 35 & 1.6 \\
\hline Japan & 11 & 26 & 73 & 2.8 & 13 & 25 & 1.9 \\
\hline Holland & 9 & 29 & 55 & 1.9 & 15 & 28 & 1.9 \\
\hline Denmark & 9 & 22 & 22 & 1.0 & 15 & 27 & 1.8 \\
\hline Australia & 8 & 32 & 62 & 1.9 & 29 & 50 & 1.7 \\
\hline Argentina & 6 & 54 & 108 & 2.0 & 29 & 48 & 1.7 \\
\hline Sweden & 4 & 26 & 44 & 1.7 & 13 & 26 & 2.0 \\
\hline Czech Republic & 2 & 12 & 34 & 2.8 & 12 & 31 & 2.6 \\
\hline Norway & 2 & 10 & 35 & 3.5 & 5 & 17 & 3.4 \\
\hline Uruguay & 2 & 13 & 48 & 3.7 & 10 & 11 & 1.1 \\
\hline Finland & 2 & 7 & 12 & 1.7 & 5 & 11 & 2.2 \\
\hline Mexico & 2 & 15 & 25 & 1.7 & 6 & 10 & 1.7 \\
\hline Ireland & 2 & 7 & 17 & 2.4 & 8 & 10 & 1.3 \\
\hline Austria & 2 & 17 & 18 & 1.1 & 7 & 7 & 1.0 \\
\hline Israel & 2 & 9 & 9 & 1.0 & 2 & 2 & 1.0 \\
\hline Russia & 1 & 22 & 101 & 4.6 & 13 & 27 & 2.1 \\
\hline Colombia & 1 & 28 & 45 & 1.6 & 15 & 19 & 1.3 \\
\hline Chile & 1 & 28 & 43 & 1.5 & 13 & 19 & 1.5 \\
\hline China & 1 & 26 & 37 & 1.4 & 16 & 19 & 1.2 \\
\hline Polland & 1 & 23 & 27 & 1.2 & 13 & 18 & 1.4 \\
\hline Switzerland & 1 & 19 & 20 & 1.1 & 10 & 13 & 1.3 \\
\hline South Africa & 1 & 6 & 9 & 1.5 & 9 & 10 & 1.1 \\
\hline New Zealand & 1 & 5 & 4 & 0.8 & 4 & 4 & 1.0 \\
\hline Slovenia & 1 & 3 & 3 & 1.0 & 2 & 3 & 1.5 \\
\hline Paraguay & 1 & 1 & 1 & 1.0 & 0 & 0 & 0.0 \\
\hline Total $^{*}$ & 632 & 328 & 2,766 & 8.43 & 301 & 1,284 & 4.26 \\
\hline
\end{tabular}

Note: ${ }^{*}$ The sample considers the countries where UFSCar's teachers had their foreign education (Ph.D. or post-doctoral level). The Total is not the sum of the columns, but the overall total including 64 other countries where UFSCar teachers did not have their education in Ph.D. or post-doctoral levels.

Source: Elaborated by the authors (2020). 
analyzing the volume of publications, the group with a foreign formation has 270 articles published in Latin American countries, while the group without such formation has 107 articles, 2.5 times less. The larger cooperation with Latin American countries reflects investments in the domains of Science, Technology, and Innovation, human resources, economic factors, and interests in the development of regional science in Latin countries in the last decades (Santin; Caregnato, 2019).

Agreements and covenants for international cooperation are ways of deepening internationalization. Federal University of São Carlos teachers' cooperation in those terms is most salient with Norwegian centers and specialists, with 3.5 articles per teacher with foreign formation and 3.4 for those without it. Federal University of São Carlos's Secretaria Geral de Relações Internacionais (General Secretariat for International Relations) has a covenant with Oslo Metropolitan University, aiming to foster joint research and academic activities in the mid and long term.

Countries like Russia were teacher-formation sites and despite no current institutional covenants, the volume of collaborative publications stands out (101 articles, with 4.6 articles for teachers with foreign formation and 2.1 for those without foreign formation). These publications result from the collaboration established by 22 teachers with foreign formation, demonstrating that the collaboration established by those professionals is not limited to the countries where they earned degrees, but that international formation generally strengthens the institution's international network of collaboration. According to Lombas (2013), more exposition to the international scientific environment (Ph.D. or post-doctorate levels abroad) favors the diversification initiatives for approaching this environment.

The graphic representation of the teachers in UFSCar with and without foreign formation in relation to the number of scientific publications with international collaboration is seen in Figure 2. Taking the number of citations into account, we notice that in our sample, the group with international formation had more citations than the one with national formation - 130,311 citations in 9,249 articles against 68,950 citations in 5,697 articles, an average of 14.1 citations per article versus 12.1 citations per article. The difference is not significant, making it crucial to expand investigations on this distribution.

The indicators of citations available in the WoS are based on the number of citations for each publication in the database, reflecting the impact, influence, or visibility of the cited articles or authors in the scientific community (Glänzel; Moed, 2002). Among the groups with and without international education, the articles-per-teacher and the WoS-citations-per-teacher ratios are relevant, both with significant numbers among the teachers who graduated abroad. One may affirm that this group is more productive, with 3.3 times more articles per teacher, and that their publications are more visible and cited.

In Figure 2, one may see that the main foreign countries for teacher education are also the most important scientific collaborators, especially the United States, the United Kingdom, France, Spain, Canada, and Germany. This is true for both groups of teachers, but the ones without foreign education present a smaller number of publications. These data are in accordance with the international trend of international mobility presented in Burrelli (2010) and National Science Foundation (2018).

Besides the scientific collaboration with the 33 countries where the teachers had their formation, UFSCar has international co-authorships with 71 countries. The ranking of UFSCar's 102 countries of international authorship is presented in Table 3.

Federal University of São Carlos's international scientific collaboration with countries where teachers "did not" have their formation amounts to 275 articles written by 91 teachers. Out of those, 240 were published by 60 teachers with international education, whereas 115 were published by 31 teachers without such formation. The total number of articles published by the two groups does not correspond to the total of articles, as one single publication may have two or more teachers from both groups as authors. Although not a significant volume in comparison to UFSCar's general production of scientific articles, this reveals the plurality of international co-authorship involving UFSCar teachers and researchers from foreign institutions. 


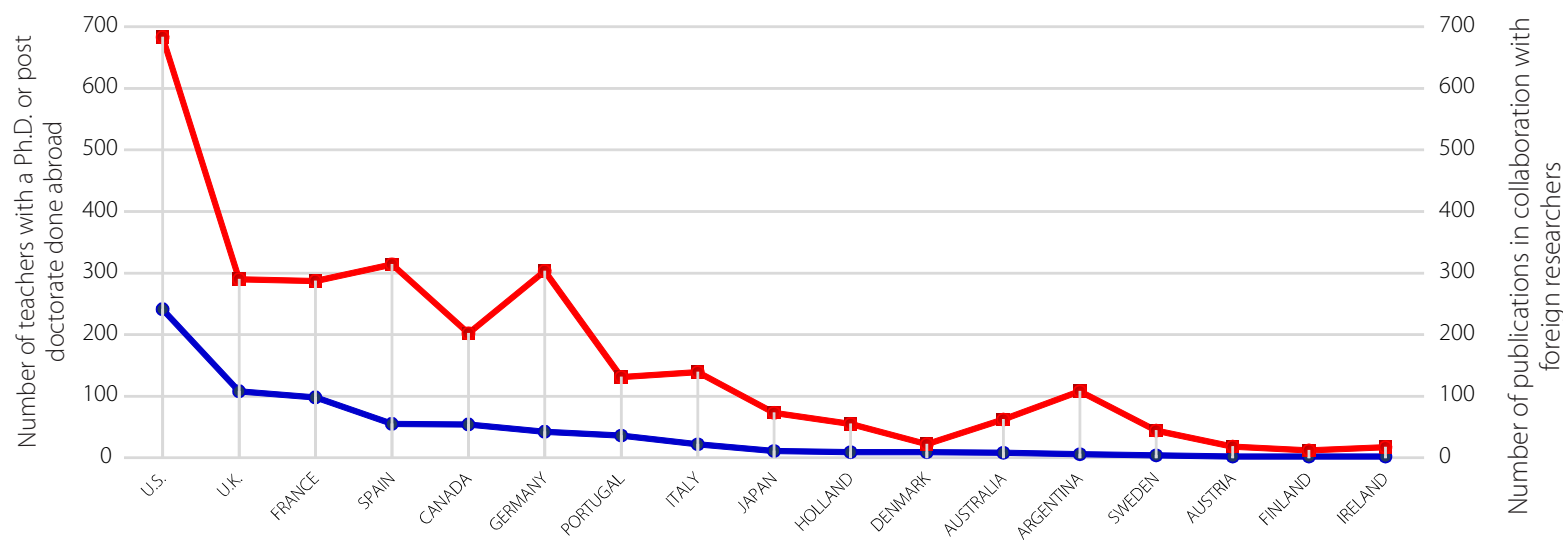

Without a Ph.D. or post doctorate abroad

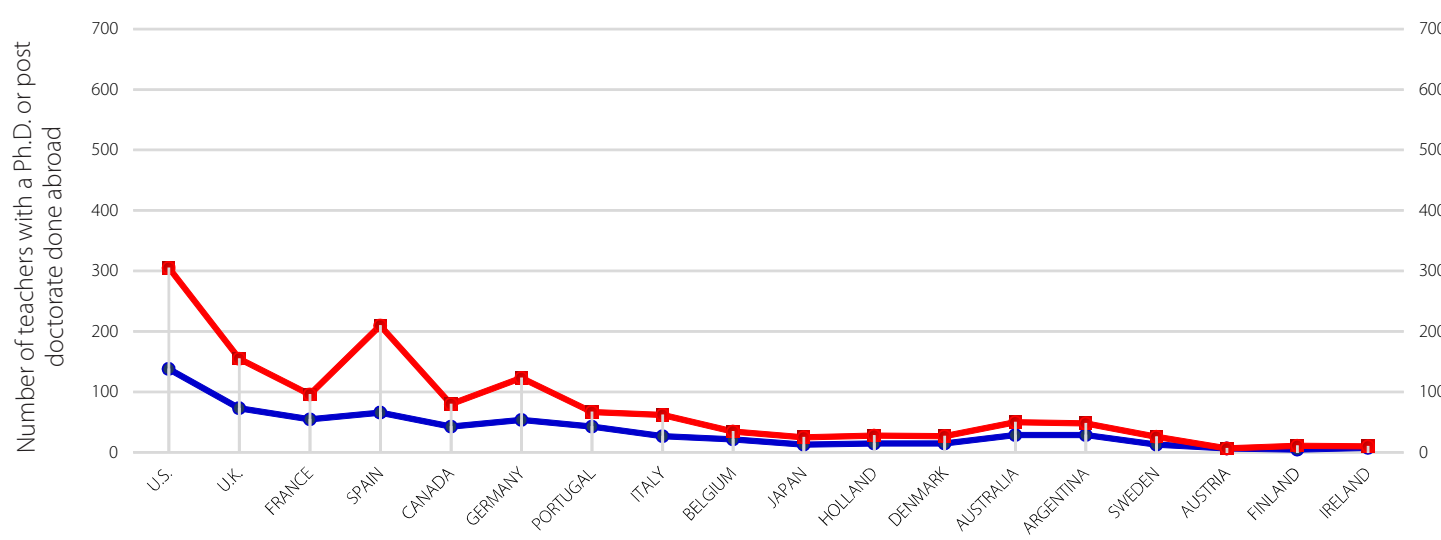

\begin{tabular}{lcccccc}
\hline & Teachers & Articles & Article/teacher & WoS citations & WoS citations/articles & WoS citations/teachers \\
\hline With foreign formation & 632 & 9,249 & 14.6 & 130,311 & 14.1 & 206.2 \\
\hline Without foreign formation & 1,283 & 5,697 & 4.4 & 68,950 & 12.1 & 53.7 \\
\hline Total & 1,915 & 12,787 & 6.7 & 166,993 & 13.1 & 87.2 \\
\hline
\end{tabular}

Figure 2 - Number of publications with international collaboration from UFSCar teachers with and without foreign formation. Note: Article/teacher means number of articles divided by the number of teachers. WoS citations/articles means number of WoS citations divided by the number of articles, and WoS citations/teachers means number of WoS citations divided by the number of teachers. WoS: Web of Science. Source: Elaborated by the authors (2020).

Among the main countries in collaboration with UFSCar's teachers, Cuba and Malaysia take up the $11^{\text {th }}$ and $14^{\text {th }}$ positions in the volume of published articles, respectively. There are no cases of UFSCar teachers having their education in these countries. The collaboration with Cuba amounts to 96 articles by 32 teachers in UFSCar (23 of the group with foreign education and 9 from the group without it). We identified the number of authors affiliated to Cuban institutions using the WoS's metadata on institutional affiliation and verified if they had Lattes resumés. Fourteen of the nineteen Cuban co-authors had Lattes resumés, in which we could understand their connections with the university: 5 (26\%) were or had been Ph.D. or post-doctorate students in UFSCar; 3 (16\%) had been visiting scholars or researchers; 5 (26\%) did not have affiliations as students or faculty; 1 teacher (5\%) did not have a complete Lattes profile, and 5 people (26\%) did not have Lattes profiles at all. Thus, while no teachers in UFSCar had 
Table 3 - UFSCar's ranking of countries and number of articles in international co-authorship.

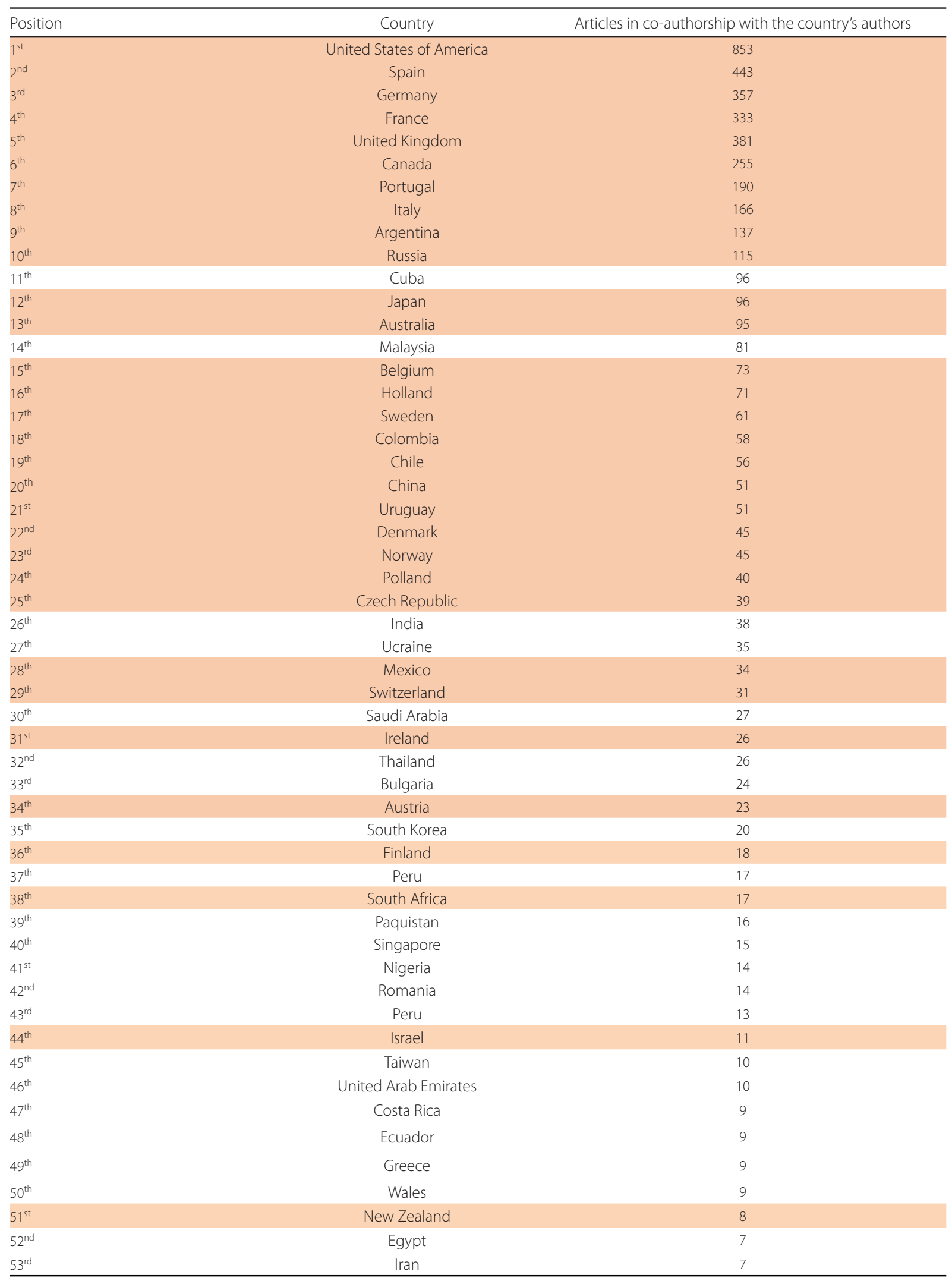


Table 3 - UFSCar's ranking of countries and number of articles in international co-authorship.

\begin{tabular}{|c|c|c|}
\hline Position & Country & Articles in co-authorship with the country's authors \\
\hline$\overline{54^{\text {th }}}$ & Venezuela & 7 \\
\hline $55^{\text {th }}$ & Slovenia & 6 \\
\hline $56^{\text {th }}$ & Senegal & 5 \\
\hline $57^{\text {th }}$ & Vietnam & 5 \\
\hline $58^{\text {th }}$ & Hungary & 4 \\
\hline $59^{\text {th }}$ & Kenia & 4 \\
\hline $60^{\text {th }}$ & Algeria & 3 \\
\hline $61^{\text {st }}$ & Bangladesh & 3 \\
\hline $62^{\text {nd }}$ & Panama & 3 \\
\hline $63^{\text {rd }}$ & Serbia & 3 \\
\hline $64^{\text {th }}$ & Armenia & 2 \\
\hline $65^{\text {th }}$ & Croacia & 2 \\
\hline $66^{\text {th }}$ & Guinea-Bissau & 2 \\
\hline $67^{\text {th }}$ & Iceland & 2 \\
\hline $68^{\text {th }}$ & Indonesia & 2 \\
\hline $69^{\text {th }}$ & Iraq & 2 \\
\hline $70^{\text {th }}$ & Lithuania & 2 \\
\hline $71^{\text {st }}$ & Mozambique & 2 \\
\hline $72^{\text {nd }}$ & Tanzania & 2 \\
\hline $73^{\text {rd }}$ & Tunisia & 2 \\
\hline $74^{\text {th }}$ & Uganda & 2 \\
\hline $75^{\text {th }}$ & Zambia & 2 \\
\hline $76^{\text {th }}$ & Bahrain & 1 \\
\hline $77^{\text {th }}$ & Bolivia & 1 \\
\hline $78^{\text {th }}$ & Cameroon & 1 \\
\hline $79^{\text {th }}$ & Dominican Republic & 1 \\
\hline $80^{\text {th }}$ & El Salvador & 1 \\
\hline $81^{\text {st }}$ & Estonia & 1 \\
\hline $82^{\text {nd }}$ & Etiopia & 1 \\
\hline $83^{\text {rd }}$ & Federal Republic Germany & 1 \\
\hline $84^{\text {th }}$ & Fiji & 1 \\
\hline $85^{\text {th }}$ & Georgia & 1 \\
\hline $86^{\text {th }}$ & Ghana & 1 \\
\hline $87^{\text {th }}$ & Jamaica & 1 \\
\hline $88^{\text {th }}$ & Jordania & 1 \\
\hline $89^{\text {th }}$ & Kosovo & 1 \\
\hline $90^{\text {th }}$ & Lybia & 1 \\
\hline $91^{\text {st }}$ & Macedonia & 1 \\
\hline $92^{\text {nd }}$ & Malawi & 1 \\
\hline $93^{\text {rd }}$ & Malta & 1 \\
\hline $94^{\text {th }}$ & New Caledonia & 1 \\
\hline $95^{\text {th }}$ & Niger & 1 \\
\hline $96^{\text {th }}$ & North Korea & 1 \\
\hline $97^{\text {th }}$ & Oman & 1 \\
\hline $98^{\text {th }}$ & Paraguay & 1 \\
\hline $99^{\text {th }}$ & Reunion & 1 \\
\hline $100^{\text {th }}$ & Rwanda & 1 \\
\hline $101^{\mathrm{st}}$ & Slovakia & 1 \\
\hline $102^{\text {nd }}$ & Union of Soviet Socialist Republics & 1 \\
\hline
\end{tabular}

Note: The countries where teachers in UFSCar had parts of their education are highlighted in the table.

Source: Elaborated by the authors (2020). 
graduated in Cuba, co-authorship relied on Cuban researchers graduating in Brazil, 5 (26\%) of them in UFSCar and 9 (47\%) in other institutions. According to Cunha-Melo (2015), whereas investing in national researchers'stages and internships abroad is critical, offering the conditions for foreign students and scholars to contribute with national research is also crucial for raising up to international scientific standards, as the case of UFSCar and Cuba highlights.

As for Malaysia, out of the 81 articles in co-authorship with UFSCar researchers (16 teachers), 76 have been published by only 10 teachers who graduated abroad, and 37 articles were published by six researchers who did not graduate abroad. The 11 authors affiliated with Malaysian institutions do not have Lattes profiles and no formal relations of cooperation were identified between UFSCar and Malaysian institutions. This suggests that in this case the cooperation is related to other factors, like the field of work and similar interests.

The results show that most teachers in UFSCar received their titles and education in Brazilian institutions and that the majority of those who went abroad got their post-doctorate (and not their Ph.D.) titles there (Table 1). The most important productivity indicator (articles per teacher) is not necessarily achieved in English-speaking countries, as Table 2 shows. The analysis of the distribution of articles published in co-authorship with foreign researchers shows a plurality of international authorship in cooperation settings (Table 3 ). The indicators show that getting the Ph.D. or post-doctorate degrees abroad contributes to forming networks of cooperation and consequently, to increasing the impact of the institutional scientific production, confirming the findings of Lombas (2013), Ramos (2018), and Grácio et al. (2018).

\section{Conclusion}

The results of the research highlighted a larger number of publications and citations of indexed articles in the WoS from teachers who had their Ph.D. or post-doctorate education abroad compared to those who did not have international experience. International co-authorship significantly contributed to increasing UFSCar's scientific production with international co-authorships. The teachers' mobility occurs mostly in the United States, United Kingdom, France, Spain, and Canada. Their proximity to the international scientific community generated relations of cooperation among the researchers through co-authorship of the institutional scientific output.

Part of UFSCar's teachers earned their Ph.D. or post-doctorate level in Brazil. Foreign researchers also come to the institution. This signals UFSCar's recognition in national scientific communities, also attested by its naming as a regional pole of interest to the education of Cuban researchers. The conditions provided by Brazilian institutions in terms of education and scientific development are related to the actions of the Sistema Nacional de Pós-Graduação, (SNPG, National Graduate System) in Brazil.

The making of indicators on the impact of teachers' formation in international co-authorship was enabled by the systematic recovery of information from different sources, the fusion of bibliographic records, and the enrichment of the data on scientific production and teacher education. Future investigations may apply these indicators to analyze the impact of strategies and policies in internationalizing Brazil's SNPG. They may also invest in understanding researchers' choices regarding national or international mobility, considering expertise, scientific production indexes, visibility, and position in institutional evaluation rankings.

The results may contribute to improving internationalization initiatives. For instance, they may subsidize making indicators for scientific and technological production in Brazil. By powering the understandings of internationalization and international co-authorship based on the impact of teacher education, they may lead to an improved SNPG.

\section{Acknowledgments}

We thank Mesailde Souza de Oliveira Matias and Paulo Matias for developing our method and for their support during the extraction of data with SyncLattes. 


\section{Contributors}

All authors contributed substantially at the stages of conception and design, analysis and interpretation of data and discussion of the results and revision of the final version of the article.

\section{References}

Aman, V. Transfer of knowledge through international scientific mobility: introduction of a network-based bibliometric approach to study different knowledge types. Quantitative Science Studies, v. 1, n. 2, p. 565-581, 2020.

Bassoli, M. Avaliação do Currículo Lattes como fonte de informação para construção de indicadores: o caso da UFSCar. 2017. Dissertação (Mestrado em Ciência, Tecnologia e Sociedade) - Universidade Federal de São Carlos, São Carlos, 2017.

Bonaccorsi, A.; Thoma, G. Institutional complementarity and inventive performance in nano science and technology. Research Policy, v. 36, p. 813-831, 2007.

Bonaccorsi, A.; Vargas, J. Proliferation dynamics in new sciences. Research Policy, v. 39, p. 1034-1050, 2010.

Bordons, M.; Gómez, I. Collaboration networked in science. In: Cronin, B.; Atkins, H. B. The web of knowledge: a festschrift in honor of Eugene Garfield. New Jersey: ASIS, 2000. p. 197-214.

Burrelli, J. Foreign science and engineering students in the United States. Infobrief, Arlington, Jul. 2010. Available from: https://files.eric.ed.gov/fulltext/ED510865.pdf. Cited: Jul. 3, 2020.

Caribé, R. D. C. D. V. Comunicação científica: reflexões sobre o conceito. Informação \& Informação, v. 25, n. 3, p. 89-104, 2015.

Conselho Nacional de Desenvolvimento Científico e Tecnológico. Sobre a plataforma Lattes. Brasília: CNPQ, 2020. Disponível em: http://memoria.cnpq.br/web/portal-lattes/ sobre-a-plataforma. Acesso em: 06 jan. 2020.

Coordenação de Aperfeiçoamento de Pessoal de Nível Superior. Programa Institucional de Internacionalização CAPES/PrInt. Brasília: CAPES, 2020. Disponível em: https:// www.gov.br/capes/pt-br/acesso-a-informacao/acoese-programas/bolsas/bolsas-e-auxilios-internacionais/ informacoes-internacionais/programa-institucional-deinternacionalizacao-capes-print. Acesso em: 27 out. 2021.

Craft, A. R. Electronic resources forum-managing researcher identity: tools for researchers and librarians. Serials Review, v. 46, n. 1, p. 44-49, 2020.

Cugmas, M. et al. Scientific collaboration of researchers and organizations: a two-level blockmodeling approach. Scientometrics, n. 125, p. 2471-2489, 2020.

Cunha-Melo, J. R. Effective indicators for science internationalization. Revista do Colégio Brasileiro de Cirurgiões, v. 42, p. 20-25, 2015. Suppl. 1.

Damaceno, R. J. P. et al. The Brazilian academic genealogy: evidence of advisor-advisee relationships through quantitative analysis. Scientometrics, v. 119, p. 303-333, 2019.
Dias, T. M. R. et al. Um estudo sobre a rede de colaboração científica dos pesquisadores brasileiros com currículos cadastrados na Plataforma Lattes. Em Questão, v. 25, n. 1, p. 63-86, 2019.

Franco, N. M. G.; Faria, L. I. L. Colaboração científica intraorganizacional: análise de redes por coocorrência de palavras-chave. Em Questão, v. 25, n. 1, p. 87-110, 2019.

Fujita, M. S. L.; Tolare, J. B. Vocabulários controlados na representação e recuperação da informação em repositórios brasileiros. Informação \& Informação, v. 24, n. 2, p. 93-125, 2019.

Gibbons, M. et al. The new production of knowledge: the dynamics of science and research in contemporary societies. London: Sage, 1994.

Glänzel, W.; Moed, H. F. Journal impact measures in bibliometric research. Scientometrics, v. 53, n. 2, p. 171-193, 2002.

Grácio, M. et al. As redes de colaboração científica nos rankings universitários e a América Latina. In: Marcovitch, J. (org.). Repensar a universidade: desempenho acadêmico e comparações internacionais. São Paulo: Fapesp, 2018. Disponível em: http://www.livrosabertos.sibi.usp.br/portaldelivrosUSP/ catalog/book/224. Acesso em: 3 jul. 2020.

Granja, C. D. Internacionalização e mobilidade estudantil: o programa Ciência sem Fronteiras na Universidade Estadual de Campinas. 2018. Dissertação (Mestrado em Política Científica e Tecnológica) - Universidade Estadual de Campinas, Campinas, 2018. Disponível em: http://repositorio.unicamp.br/jspui/ handle/REPOSIP/331547. Acesso em: 3 jul. 2020.

Hicks, D. et al. Bibliometrics: the Leiden Manifesto for research metrics. Nature, v. 520, n. 7548, p. 429-431, 2015.

Katz, J. S.; Martin, B. R. What is research collaboration? Research Policy, v. 26, n. 1, p. 1-18, 1997.

Lança, T. A. et al. Multi e interdisciplinaridade nos programas de pós-graduação em Ciência da Informação brasileiros. Perspectivas em Ciência da Informação, v. 23, n. 4, p. 150-183, 2018.

Lombas, M. L. S. A mobilidade internacional de pós-graduandos e pesquisadores e a internacionalização da produção do conhecimento: efeitos de uma política pública no Brasil. 2013. Tese (Doutorado em Sociologia) - Universidade de Brasília, Brasília, 2013. Disponível em: https://repositorio.unb.br/ handle/10482/15438. Acesso em: 3 jul. 2020.

Madeira, R. M.; Marenco, A. Os desafios da internacionalização: mapeando dinâmicas e rotas da circulação internacional. Revista Brasileira de Ciência Política, n. 19, p. 47-74, 2016.

Matias, M. S. O. Base referencial para o povoamento de repositórios institucionais: coleta automatizada de metadados da 
Plataforma Lattes. 2015. Dissertação (Mestrado em Gestão de Organizações e Sistemas Públicos) - Universidade Federal de São Carlos, São Carlos, 2015.

Mena-Chalco, J. P. et al. Caracterizando as redes de coautoria de currículos Lattes. In: Brazilian Workshop on Social Network Analysis and Mining (BraSNAM), 1., 2012, Curitiba. Anais [...]. Porto Alegre: Sociedade Brasileira de Computação, 2012.

National Science Foundation. Foreign-born students and workers in the U.S. Science and Engineering Enterprise. National Science Board, 2018. Available from: https://www. nsf.gov/nsb/publications/2018/foreign-born-one-pager.pdf. Cited: Jul. 3, 2020.

Prolo, I. et al. The internationalisation of Brazilian Universities: contributions of the 'Science Without Borders' Programme. Administração: Ensino e Pesquisa, v. 20, n. 2, p. 603-609, 2019.

Radael, W. H. et al. Análise do perfil da internacionalização da pós-graduação de uma universidade pública no Brasil: formação no exterior. In: Congresso de Internacionalização da Educação Superior, 1., 2019, Foz do Iguaçu. Anais [....]. Foz do Iguaçu: UNILA, 2019. p. 143-144.
Ramos, M. Y. Internacionalização da pós-graduação no Brasil: lógica e mecanismos. Educação e Pesquisa, v. 44, e161579, 2018.

Santin, D. M.; Caregnato, S. E. Perfil científico da América Latina e Caribe no início do século XXI. In: Encontro Nacional de Pesquisa em Ciência da Informação, 20., 2019, Florianópolis. Anais eletrônicos [...]. Florianópolis: UFSC, 2019. Disponível em: http://hdl.handle.net/10183/202722. Acesso em: 20 jul. 2020.

Thiengo, L. C. et al. Rankings acadêmicos e universidades de classe mundial: relações, desdobramentos e tendências. Educação \& Sociedade, v. 39, n. 145, p. 1041-1058, 2018.

TheTimes Higher Education Ranking. World University Rankings, 2021. Available from: https://www.timeshighereducation.com/ world-university-rankings/2021/world-ranking. Cited: Mar. 3, 2021.

Yao, X. et al. Global village or virtual balkans? evolution and performance of scientific collaboration in the information age. Journal of the Association for Information Science and Technology, v. 71, n. 4, p. 395-408, 2020.

Zhang, C. et al. Understanding scientific collaboration: homophily, transitivity, and preferential attachment. Journal of the Association for Information Science and Technology, v. 69, n. 1, p. 72-86, 2018. 


\section{ERRATUM}

In article "Impact of teacher education abroad in international co-authorship: a study of Federal University of São Carlos's scientifics production indexed in the Web of Science" with DOI: 10.1590/2318$0889202133 e 200061$ published in Transinformação, 2021, 33, e200061 in the first page.

\section{Where is read}

Como citar este artigo/How to cite this article

Reis, J. E. et al. Impact of teacher education abroad in international co-authorship: a study of Federal University of São Carlos's scientifics production indexed in the Web of Science. Transinformação, v. 32, e200061, 2021. https://doi.org/10.1590/2318-0889202133e200061

\section{Should read}

Como citar este artigo/How to cite this article

Reis, J. E. et al. Impact of teacher education abroad in international co-authorship: a study of Federal University of São Carlos's scientifics production indexed in the Web of Science. Transinformação, v. 33, e200061, 2021. https://doi.org/10.1590/2318-0889202133e200061 